\title{
The Role of Local Hydromacrophytes in Leachate Phytoremediation Performed Using Constructed Wetland System
}

\author{
Sophia Laily ${ }^{1 *}$, Bagyo Yanuwiadi ${ }^{2}$, Catur Retnaningdyah² \\ ${ }^{1}$ Master Program of Environmental Management and Development, Graduate School, University of Brawijaya, Malang, \\ Indonesia \\ ${ }^{2}$ Department of Biology, Faculty of Mathematics and Natural Sciences, University of Brawijaya, Malang, Indonesia
}

\begin{abstract}
The purpose of this research is to analyze the effectiveness of using local hydromacrophytes for performing leachate phytoremediation in constructed wetland (CW) system. It was an ex situ experiment carried out in a glass house by means of free water surface (FWS) CW reactors containing sand and gravel substrates in 3:5 ratio. The reactor was waterlogged by $9 \mathrm{~L}$ leachate. The phytoremediation tests were performed in two-factor treatment design involving hydromacrophyte species and hydraulic retention time. Species of local hydromacrophyte used in this research included Alternanthera sessilis, Commelina nudiflora, Paspalum conjugatum, Typha angustifolia and the polyculture of the four species. The improvements in leachate qualities were identified through decreases of physico-chemical parameters. Among the mean values of the percentages indicating the decreases of physico-chemical leachate parameters, the greatest ones were resulted from the treatments using $T$. angustifolia and $A$. sessilis on the $30^{\text {th }}$ day. It has proven in the experiment that these two species of hydromacrophyte perform the most effective process of improving leachate quality.
\end{abstract}

Keywords: constructed wetland, leachate, local hydromacrophytes, phytoremediation.

\section{INTRODUCTION}

Waste management in final dump site that use sanitary landfill and controlled landfill systems produces methane gas and leachate as its by-products. Leachate is characterized as the external water or liquid that is percolated into heaps of solid waste and leached out the dissolved constituents including some organics materials from biological decomposition. To prevent leachate from contaminating the land and/or groundwater in its environment, it is important to have an effective leachate treatment. Sanitary landfill system in solid waste management involves the process of gathering leachate on the bottom of the landfill site by relying on gravity and channeling it into Leachate Treatment Plant $[3,7]$. Conventional Leachate Treatment Plant (LTP) has become a common facility in landfills in Indonesia for waste management purpose. The conventional method involves physical and chemical processing that is carried out in a stabilization pool (primary, secondary and tertiary treatment tanks). The resulted leachate is then disposed to the surrounding ground or recirculated to be the starter for the decomposition

\footnotetext{
* Correspondence author:

Sophia Laily

Email : sophiaovilaily@gmail.com

Address : Graduate School, University of Brawijaya, Mayjen Haryono No. 169, 65145, Malang.
}

process of another waste mass. Unfortunately, this method can only manage less than $40 \%$ of the leachate organic contents [7]. In Indonesia, the standard of leachate quality acceptable for a release to the environment is ruled by the Regulation of The Minister of Environment and Forestry, Number P.59/Menlhk/Setjen/Kum.1/7/2016 on standard leachate quality for waste control in final disposal facility.

Phytoremediation refers to the use of certain plants to remove or reduce pollutants from the ground, sediments, surface water, groundwater and liquid waste [4]. A constructed wetland (CW) with selected plants grown on it is one of methods to adopt in treating wastewater with phytoremediation. Hydromacrophyte is a type of vegetation that can be grown in $\mathrm{CW}$ to reduce the amount of pollutant substances in its environment. Different species of hydro-macrophyte perform different ways of pollutant reduction including absorbing, degrading, extracting, accumulating or stabilizing pollutant elements. The effectiveness of phytoremediation as an alternative technique in controlling wastewater has been known in many countries worldwide. Wastewater remediation in $\mathrm{CW}$ is a combination of physical, chemical and biological processes. The effectiveness of $\mathrm{CW}$ system in reducing the amount of organic, inorganic and heavy metal pollutants has been studied and tested. It is 
proven easier to apply in improving the quality of various kinds of contaminated water such as domestic wastewater, industrial wastewater, leachate and wastewater from mining industry $[1,4]$. So far there are four types of CW that have been developed for different functions or specific purposes of remediation:

1. Free water surface CW. This type resembles the natural wetland which has free water surface areas on it.

2. Subsurface water flow or vegetated submerge bed CW. In this type of CW, the water surface isn't higher than the substrate and it is only the roots of the plants that come in direct contact with the wastewater;

3. Vertical flow CW. In this type, wastewater is distributed vertically from the substrate downward along the root zone because of gravitational force;

4. Sludge dewatering beds (reed beds) CW. This type of CW applies evapotranspiration from plants to remove water from mud waste deposit [11].

Waste management in the Final Waste Disposal Site of Talangagung is carried out using sanitary landfill system and the LTP leached out the leachate that often exceeded the standard of leachate quality effluent. Because of that, the leachate from the tertiary tank in LTP is not discharged into the surrounding ground. Instead, it is re-circulated or introduced into the new batches of waste and is reused as a compost starter. Re-circulation process could results in several adverse impacts such as the increase of methane production, leachate overflowing, and the accumulation of volatile organic acid compound together with some hazardous heavy metal elements which are not easily degraded $[6,10]$. The research presented in this article aimed to analyze the effectiveness of using local hydromacrophytes for performing leachate phytoremediation in constructed wetland system.

\section{MATERIALS AND METHODS}

This research was an experiment that conducted in a glass house of Department of Biology, Faculty of Mathematics and Natural Sciences, University of Brawijaya. The applied procedure was factorial experiment in completely randomized design with two treatment factors ( 6 $x 6)$. The first factor was hydromacrophyte species and the second was hydraulic retention time (HRT). HRT is the length of time that a compound (e.g. water) remains in a storage unit. There were four species of local hydromacrophyte and their polyculture planted in CW reactors with four replications. Each of the reactors was made from plastic tank $40 \mathrm{~cm}$ in diameter and $24 \mathrm{~cm}$ in height. The reactor was filled with sand and gravel substrates in 3:5 ratio and a local hydromacrophyte was planted on it. The hydromacrophytes had previously been acclimatized in the glass house before the $9 \mathrm{~L}$ of leachate was poured into it. Four species of local hydromacrophyte used in this research were Alternanthera sessilis, Commelina nudiflora, Paspalum conjugatum and Typha angustifolia.

\section{Data Collection}

The measurement of physico-chemical parameters of leachate was performed at 6 HRT (Hydraulic Retention Time) which were plotted on the $0^{\text {th }}, 5^{\text {th }}, 10^{\text {th }}, 15^{\text {th }}, 21^{\text {st }}$, dan $30^{\text {th }}$ days in the Microbiology Laboratory and Ecology-Animal Diversity Laboratory in the Department of Biology, Faculty of Mathematics and Natural Sciences, University of Brawijaya. The leachate quality were observed in 6 parameters (Conductivity, Turbidity, TDS, BOD, Nitrate, Ortophospate). The observations of the physical conditions of the plants in the reactors were recorded and the results were documented to provide secondary data regarding local hydromacrophytes's tolerance to toxic environment.

The resulting data were tabulated using an SPSS (Statistics software program) and then analyzed by one-way ANOVA test for those data which were identified as normal and homogenous based on Levene test, and by BrownForsythe test for those which were identified as normal but not homogenous. The results from one-way ANOVA test and Brown Forsythe test that showed significant differences were further analyzed to observe the specific values of the differences using Tukey-HSD test (as the followup of ANOVA) and Games-Howell test (as the follow-up of Brown-Forsythe). Afterwards, biplot graph were applied to group and to describe the overall results of measurement/ analyses for all observed physico-chemical parameters. The percentage of decreasing leachate quality parameters also tabulated using Ms. Excel.

\section{RESULT AND DISCUSSION \\ Physico-Chemical Parameters of the Leachate Qualities}

The data that represent physico-chemical parameters of the leachate qualities in this research are normally distributed with mean values as 
presented in Supplementary 1. The biplot in Figure 1 illustrates the whole conditions of the leachate qualities throughout the allotted retention times whereas the biplot in Figure 2 illustrates those for all selections of hydromacrophyte species.

Figure 1 also shows the three groups of leachate quality measurements. The first group is represented on the right-hand quadrant of the figure and comprises the measurements for all the observed parameters on the $0^{\text {th }}$ day. The group indicates relatively high mean values for all parameters of the leachate qualities. The second group consists of the leachate quality measurements from the $5^{\text {th }}$ and $10^{\text {th }}$ days. The data obtained from the two points of retention time show insignificant differences and are therefore categorized into the same group. They indicate lower values for all parameters of leachate quality except for BOD which is still relatively high, but the values in this group has created wide gap with the first group. The rest of leachate quality data, which are obtained from the $15^{\text {th }}, 21^{\text {st }}$ and $30^{\text {th }}$ days, belong to the third group.

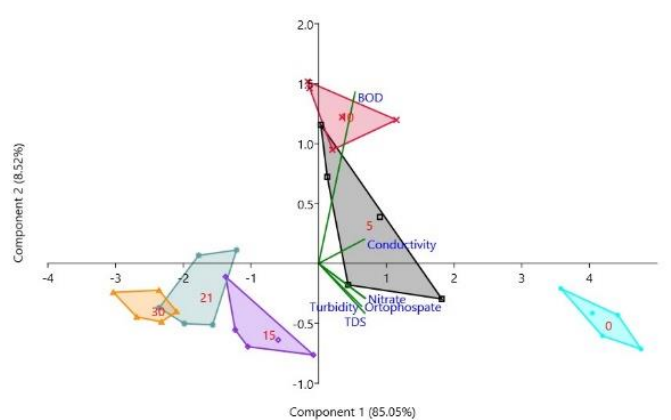

Figure 1. Biplot Graph of leachate quality parameters through out points of hydraulic retention time

It is shown in the figure that they converge on the same quadrant because their values are close to each other. The quadrant indicates a much lower measurements for all leachate quality parameters in this group compared to those in the other two groups. Furthermore, the biplot analysis of the differences in the leachate qualities in daily monitoring based on hydromacrophyte species factor is shown in Figure 2 (the $5^{\text {th }}$ day), Figure 3 (the $15^{\text {th }}$ day), and Figure 4 (the $30^{\text {th }}$ day).

The values of decreases for each physicochemical parameter of the leachate qualities are presented in detail in Supplementary 2. Which species of hydromacrophyte that had resulted in the highest value of decrease is indicated in the table.

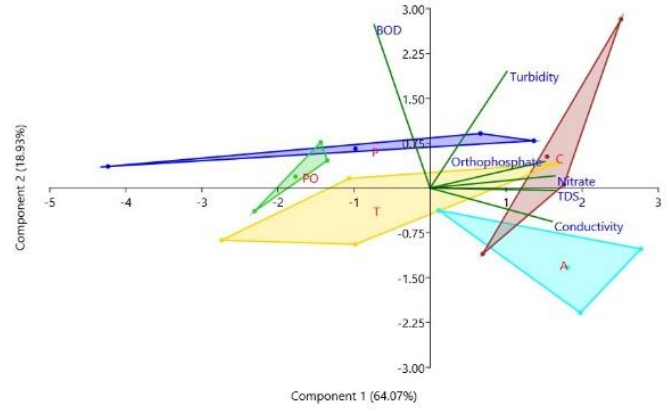

Figure 2. Biplot Graph of leachate quality parameters based on the hydromacrophyte speciestreatments on the $5^{\text {th }}$ day

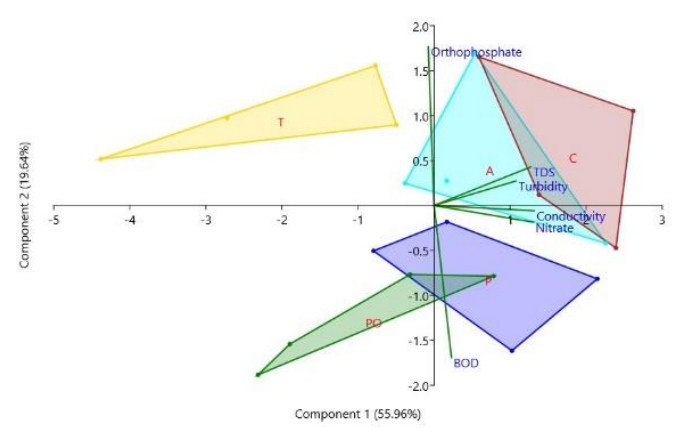

Figure 3. Biplot Graph of leachate quality parameters based on the hydromacrophyte speciestreatments on the $15^{\text {th }}$ day

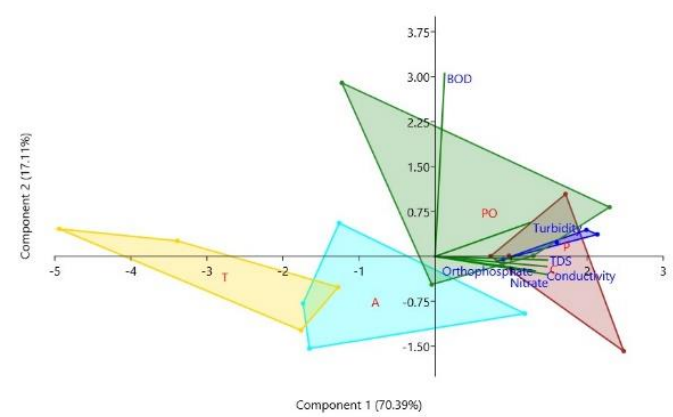

Figure 4. Biplot Graph of leachate quality parameters based on the hydromacrophyte speciestreatments on the $30^{\text {th }}$ day

The result of the biplot analysis indicates that the values representing conductivity, turbidity, TDS, nitrate and orthophosphate correlate to one another. Histograms in Figure 6 to Figure 10 represent statistically significant differences of mean values for all parameters of the leachate qualities with percentages of decreases shown above each column of the chart.

The levels of conductivity, as shown in Figure 5 , declines significantly by $55.01 \%$ to $61.05 \%$ on the $5^{\text {th }}$ day and keeps dropping until the $30^{\text {th }}$ day 
when the decreases measure $79.56 \%$ to $87.88 \%$. The levels of TDS, represented in Figure 6, generally show significant dropss ranging from $35.84 \%$ to $46.24 \%$ on the $5^{\text {th }}$ day. On the last retention time (the $30^{\text {th }}$ day), its decreases reach $55.24 \%$ to $74.04 \%$. Likewise, the levels of turbidity also make substantial decreases from the $5^{\text {th }}$ to the $30^{\text {th }}$ days as illustrated in Figure 7 . The range of the decline on the $5^{\text {th }}$ day is $29.05 \%$ to $55.32 \%$ and it is $94.90 \%$ to $97.79 \%$ on the $30^{\text {th }}$ day.

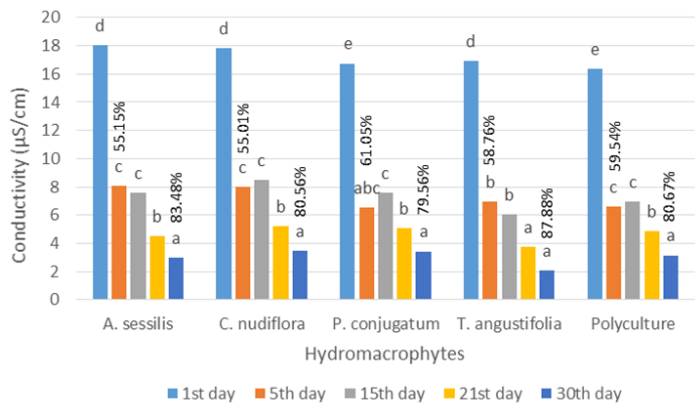

Figure 5. Mean value of conductivity measured based on HRT and hydromacrophyte species factors

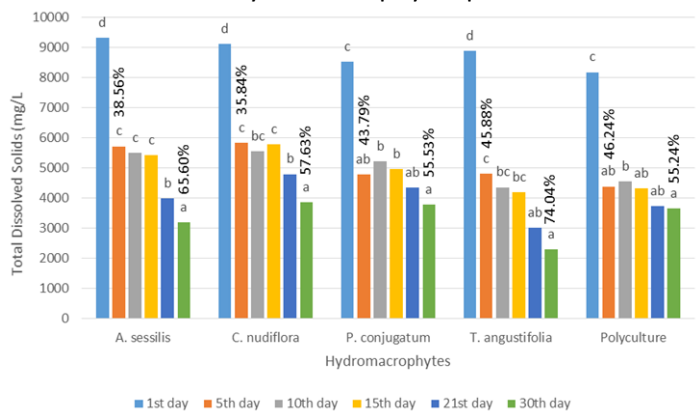

Figure 6. Mean value of TDS measured based on HRT and hydromacrophyte species factors

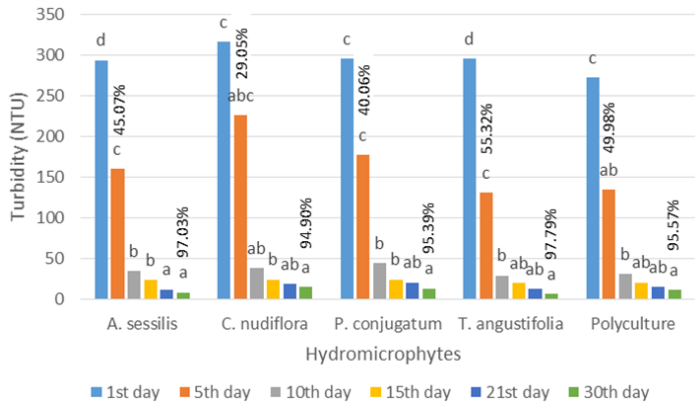

Figure 7. Mean value of turbidity measured based on HRT and hydromacrophyte species factors

The same case applies to the levels of nitrate and orthophosphate. Indicated in Figure 8, nitrate levels are dropping considerably from $57.25 \%$ to $64.33 \%$ on the $5^{\text {th }}$ day to $76.00 \%$ to $89.19 \%$ on the $30^{\text {th }}$ day. The overall of orthophosphate decreases, as indicated in Figure 9, are $42.17 \%$ to $51.94 \%$ on the $5^{\text {th }}$ day and reaches $92.17 \%$ to $97.03 \%$ on the $30^{\text {th }}$ day.

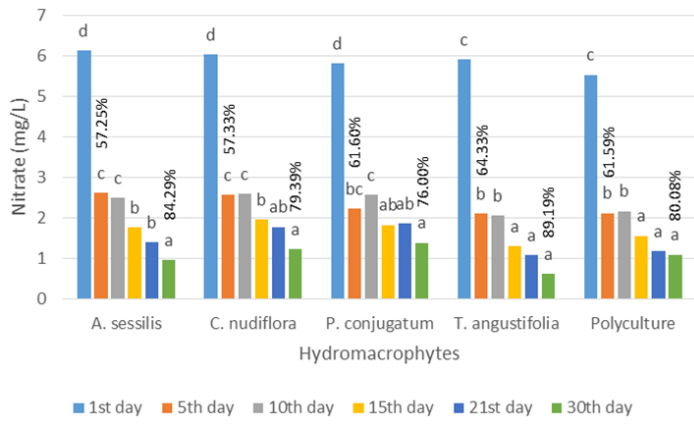

Figure 8. Mean value of nitrate measured based on HRT and hydromacrophyte species factors

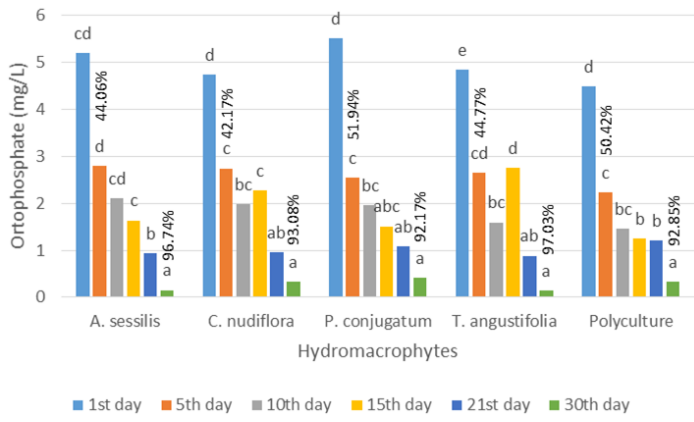

Figure 9. Mean value of ortophosphate measured based on HRT and hydromacrophyte species factors

\section{Hydromacrophyte Species}

Alternanthera sessilis has extensive distribution worldwide that encompasses tropical and subtropical regions. The natural habitats of this species of hydromacrophyte can be found in many parts of America, Africa, Australia and Asia where Indonesia is one of them. It is known as one of pioneer plants that can survive in wetland ecosystem that has suffered degradation and contamination. This weed normally grows on the edges of marshes, riparian zones, rice fields, the edges of irrigation channels and waterways, the edges of dams and roadside puddles. They can withstand an environment which is flooded by water up to 1 meter high [5]. In this research, $A$. sessilis grew very fast and were well adapted to the environment with high levels of organic contents. By the fifth day, the leaves went dry, but in the following days, the plant grew fast, forming a dense colony that covered almost the whole surface of the reactor. Several leaves were damaged by Leptosia nina, but this pest didn't hold up the plant's rapid growth. New buds were developing at the plant's nodes that grew under the water and there were no parts of the plant that died because of their submergence in the water. $A$. sessilis is an obligate wetland species that can grow well in FWS-CW in this experiment because of its tolerance to environmental stresses. 
Paspalum conjugatum can generally be found in many areas of tropical countries in American continent and it has been naturalized as far as Southeast Asia (including Indonesia) as well as several other tropical regions in the world. $P$. conjugatum is characterized by its sturdy and long stolon and its creeping growth pattern with roots at nodes, branching out and solid. They can grow well on high ground up to 1700 meters above sea level. They can also survive with or without shades but they are generally found in colony under the shade of other vegetation in riparian zones, roadsides and degraded zones [8]. In our experiment, $P$. conjugatum grew slower than expected since the leachate was poured into the reactor, from the first day up to the $30^{\text {th }}$ day. Parts of the plant that were immersed in the water were decaying and the plant was dying. It is apparent that $P$. conjugatum is not an obligate wetland species. Evidently, this species could not survive in the kind of waterlogged environment such as FWS-CW.

The natural habitat of Commelina nudiflora, like Alternanthera sessilis, covers many Asian countries with tropical and sub-tropical climates including Indonesia (U.S. National Plant Germplasm System, 2007). This plant reproduces through its seeds and stolon and can grow rapidly with abundant supply of water. Commelina nudiflora commonly grow with upright stems in dense colonies. They proliferate in a very short time and compete well with other plants for spaces and available nutrition. They can adapt to the environment with $\mathrm{pH} 4$ to 10 . They are the kind of weed that can live in various levels of humidity and light intensity. They can also tolerate cutting [1]. Commelina nudiflora in our experiment experienced inhibition in its growth since a certain amount of leachate was poured into the reactor. Its leaves went dry as its endurance was slowly weakening because of the environmental stresses impacted by the leachate. Its condition was even more deteriorating due to the presence of Bemisia tabacci that was harmful to its vigor. On the $30^{\text {th }}$ day, its biomass was nearly destroyed.

Typha angustifolia is an obligate wetland species that commonly grow in Europe but have also been naturalized in other areas in the world including Indonesia. They can survive low $\mathrm{pH}$ environment and anaerobic condition. This macrophyte grows through rhizomes and needs a lot of sunlight to survive. It is well adapted to free water surface and subsurface water flow constructed wetlands [10]. It has been widely known that
T. angustifolia is capable of reducing toxic contents in the water [10]. Several species of endophytic bacteria in T. Angustifolia's root system which are adept at adsorbing nitrogen and accelerating the plant's growth while some other species play important role in reducing nitrogen, phosphor and/or other toxic organic materials in eutrophic water [8]. Typha spp. has rhizodegradation/phytodegradation mechanism which is useful in reducing organic-aromatic and aliphatic materials, petroleum hydrocarbon contents as well as chlorinated solvent, TNT (trinitrotoluene) and pesticide [4]. The 30-day experiment in our research had proved that $T$. angustifolia was the species of hydromacrophyte with the highest performance in causing decreases in the leachate quality parameters and it adapted well to FWS type of CW.

\section{Phytoremediation in Constructed Wetland Sys- tem}

Remediation in vegetated CW system is a complex activity that involves physical processes (sedimentation, filtration and adsorption), chemical processes (coagulation, oxidation-reduction and transformation) and biological processes (decomposition of organic matter into simpler elements by certain bacteria and plant uptake in various specific ways) $[10,4]$. The impacts of each process rely on the climate, the temperature, the amount of available bacteria, the substrates and the species of the plants [10]. The choice of vegetation plays crucial role in implementing constructed wetland system. The process of plant uptake is a very useful part in the attempts of removing heavy metal elements and of reducing petroleum hydrocarbon substances, synthetic hydrocarbon, nitrate and phosphate [10]. The treatments had resulted in different mean values of decreases in physico-chemical parameters for different species of hydromacrophyte as represented in Supplementary 2.

A liquid's capability in conducting electricity is referred to as conductivity and it is measured using conductivity meter [12]. The level of conductivity is contingent to the presence of soluble inorganic ions such as sodium, calcium, iron, nitrate, magnesium and the like. The decrease in conductivity in leachate is an indication of the drop in the amount of inorganic ions in it. Sedimentation process is the first physical process to occur as a result of the gravitational force. Afterwards, the chemical processes such as adsorption, precipitation and ion exchange take place at about the same time with biological processes 
such as microbial uptake and plant uptake. The research presented in this article resulted in the finding that $T$. angustifolia was the hydromacrophyte species with the most effective role in reducing conductivity in the leachate. The next species which showed its effectiveness in reducing conductivity is $A$. sessilis with $7 \%$ lower than $T$. angustifolia's effectiveness in the same function for all points of HRT.

It was found that TDS positively is correlated to conductivity because the level of TDS signifies the amount of soluble solid present including inorganic matter such as those mentioned earlier. The decrease in conductivity will result in the decrease in TDS level as well. It is then evident that $T$. angustifolia played the most effective role in reducing TDS level in leachate. It was $7.32 \%$ to $10.96 \%$ more effective than $A$. sessilis which came in second for the same role.

Turbidity refers to the extent to which suspended solids occur in the water. The suspended solids consist of planktons and other microorganisms, fine sand, and organic and inorganic solids. The decrease in turbidity level is primarily caused by gravitational force that makes them go down to settle on and to be adsorbed by CW substrates or form biofilms on the surface of sand and gravel substrates. Biofilm is the mass of microorganism which is present in colonies and plays important role in the decomposition of organic matter in leachate. CW of FWS type is an effective method of reducing turbidity by up to $90 \%$. It was found in the experiment that $T$. angustifolia is capable of reducing turbidity more effectively than $A$. sessilis. The difference between the two species in this particular performance was $10.25 \%$ on the $5^{\text {th }}$ day and it was declining throughout the following retention times well into the $30^{\text {th }}$ day.

Nitrate $\left(\mathrm{NO}_{3}\right)$ is the most stable form of nitrogen in the water and can be immediately taken in by plants. Nitrate content in the water can decline as the result of microbial uptake and plant uptake apart from sedimentation and adsorption on CW substrates. A research has been reported that the amount of nitrogen removed by plant uptake does not exceed $10 \%$ of the total removed nutrients (both nitrogen and phosphorous) even in optimum conditions [11]. As in the other cases previously mentioned, $T$. angustifolia was recorded as the most effective species in decreasing nitrate level in the leachate, $8 \%$ higher than $A$. sessilis's effectiveness for the same performance.
Orthophosphate is one of inorganic phosphates in the water. It is a form of phosphor that can be absorbable by the hydromacrophytes and algae. The decrease in the amount of phosphate in the water was mainly resulted from sedimentation, precipitation, adsorption, microbial uptake (phytoplankton uptake) and plant uptake. The finding of our experiment showed that $T$. angustifolia was the hydromacrophyte species with the highest performance in decreasing the amount of orthophosphate in the leachate. Its uptake of phosphorus was $5 \%$ more effective than $A$. sessilis's.

BOD (Biochemical Oxygen Demand) describes the amount of biodegradable organic matter in contaminated water. BOD is measured by the amount of oxygen needed by the bacteria to degrade the existing organic substance in the water. Leachate contains high level of BOD and it usually takes a long time to reduce it. The length of time needed in attaining significant decrease of BOD depends on the leachate's condition (anaerobic or aerobic). On the $5^{\text {th }}$ day of our experiment, we hadn't had significant decrease in BOD level in general, but in $\mathrm{CW}$ reactor vegetated with A. sessilis, there had been observable BOD decrease at $37.92 \%$. The significant decrease was most apparent on the $30^{\text {th }}$ day which reached $76.28 \%$ to $90.87 \%$ in values. $A$. sessilis was recorded as the species with highest achievement in reducing the level of $B O D$ in the leachate. The differences in the habitus possessed by $A$. sessilis and $T$. angustifolia led to a greater increase in BOD by $A$. sessilis. $A$. sessilis is an obligate wetland plant that is resistant to the exposure of leachate even to newly emerging shoots that is waterlogged by leachate. BOD will be decreasing when the amount of soluble oxygen in the water is increasing. The transfer of oxygen that takes place in every part of $A$. sessilis will supply the wastewater with sufficient oxygen to achieve the desired aerobic condition in $A$. sessilis-based leachate treatment. The aerobic condition is necessary for the bacteria to decompose the present organic matter easier and faster.

Based on the overall results of the research, it can be summarized that the most effective leachate phytoremediation was achieved when using $T$. angustifolia in FWS-CW. It had contributed to the decreases in the parameters of conductivity, turbidity, TDS, nitrate and orthophosphate by $87.87 \%, 97.79 \%, 74.04 \%, 89.19 \%$ and $97.03 \%$ respectively on the $30^{\text {th }}$ day. The second most effective leachate phytoremediation was attained when the FWS-CW was vegetated with $A$. 
sessilis. On the $30^{\text {th }}$ day, it had contributed to the decreases in the parameters of conductivity, turbidity, TDS, BOD, nitrate and orthophosphate by $83.48 \%, 97.03 \%, 65.60 \%, 90.87 \%, 84.29 \%$ and $96.74 \%$ respective-ly.

\section{CONCLUSION}

The effectiveness of leachate phytoremediation that makes use of local hydromacrophytes in constructed wetland system in this research has been proven. It through a series of experiments that involve treatments in $\mathrm{CW}$ reactors with four different species of vegetation and their polyculture and a number of hydraulic retention times. It has been found that the two of those local hydromacrophytes have higher levels of reduction in all physico-chemical parameters of leachate qualities than others. Those species are Typha angustifolia and Alternanthera sessilis. T.angustifolia and $A$. sessilis are made greatest decreases on each retention time. T. angustifolia attained $87.88 \%$, $97.79 \%, 74.04 \%, 87.24 \%, 89.19 \%$, and $97.03 \%$ reductions of conductivity, turbidity, TDS, BOD, nitrate and orthophosphate parameters respectively on the $30^{\text {th }}$ day. $A$. sessilis caused $83.48 \%, 97,03 \%, 65.60 \%, 90.87 \%, 84.29 \%$, and $96.74 \%$ reductions of conductivity, turbidity, TDS, BOD, nitrate and orthophosphate parameters respectively on the $30^{\text {th }}$ day.

\section{ACKNOWLEDGEMENT}

I would like to thank the manager of Final Waste Disposal Site of Talangagung, Kepanjen, Malang Regency, for letting me have some material for my experiment. I would also like to express my deepest gratitude to the district government of Malang Regency, for granting me the opportunity of pursuing my master degree in the Master Program of Environmental Management and Development, Brawijaya University.

\section{REFERENCES}

[1] Anonymous. 2003. The use of Constructed Wetlands for Wastewater Treatment. Wetland International. Malaysia.

[2] Atkinson, J. L. 2014. Biology, ecology, and control of Doveweed (Murdannia nudiflora $\mathrm{L}$. Brenan). PhD Thesis. Clemson University.

[3] Damanhuri, E. 2008. Diktat landfilling limbah. ITB. Bandung.

[4] Dhir, B. 2013. Phytoremediation: Role of aquatic plants in environmental clean-up. Springer. India.
[5] Gupta, A.K. 2014. Alternanthera sessilis. The IUCN Red List of Threatened Species. http://dx.doi.org/10.2305/IUCN.UK.20141.RLTS.T164480A49527118.en.

[6] Hernández-Berriel, M. C., M.C. Mañón-Salas, O. Buenrostro-Delgado, J. M. Sánchez-Yáñez and L.M. Márquez-Benavides. 2014. Landfill Leachate Recirculation (Part 1 : Solid Waste Degradation and Biogas Production). Environ. Eng. Manage. J. 3(10). 2687-2695.

[7] Ministry of Public Work. 2013. Ministry Regulation No. 03/PRT/M/2013 on the Implementation of waste infrastructure and facility in household waste management and household garbage. Republic of Indonesia. Jakarta.

[8] Li, Y. H, Q. F. Liu, Y. Liu, J. N. Zhu and Q. Zhang. 2010. Endophytic bacterial diversity in roots of Typha angustifolia $L$. in the constructed Beijing Cuihu Wetland, China. Journal of Elsevier. Res. Microbiol. 162 (2010). 124-131.

[9] Mannetje, L.'t and R.M. Jones (Eds). 1992. PROSEA (Plant resources of South-East Asia) Foundation. Bogor. Available: http://www. feedipedia. org.

[10] Sawatdeenarunat, C. 2010. Effects of leachate recirculation on anaerobic treatment of municipal solid waste. Proceeding of $3^{\text {rd }}$ International Conference on Geoinformation Technology for Natural Disaster Management and Rehabilation. 4(1), 448.

[11] Wallace, S. D. and R. L. Knight. 2006. Smallscale constructed wetland treatment systems : feasibility, design criteris, and O\&M requirements. Water Environment Research Foundation. USA.

[12] Clesceri, L. S., A. E. Greenberg and A. D. Eaton. 1999. Standard Methods for The Examination of Water and Waste Water, $20^{\text {th }}$ Ed. Washington DC. USA. 